\title{
Comparative Study on the Effects of Surface Area, Conduction Band and Valence Band Positions on the Photocatalytic Activity of $\mathrm{ZnO}-\mathrm{M}_{\mathrm{x}} \mathrm{O}_{\mathrm{y}}$ Heterostructures
}

\author{
Mysore Byrappa Nayan', Krishnegowda Jagadish', Mavinakere Ramesh Abhilash1, \\ Keerthiraj Namratha ${ }^{2,3}$, Shivanna Srikantaswamy ${ }^{{ }^{*}}$ \\ ${ }^{1}$ Department of Studies in Environmental Science, University of Mysore, Mysuru, India \\ ${ }^{2}$ Center for Materials Science and Technology, Vijnana Bhavana, University of Mysuru, Mysuru, India \\ ${ }^{3}$ Department of Studies in Earth Science, University of Mysore, Mysuru, India \\ Email: *srikantas@hotmail.com
}

How to cite this paper: Nayan, M.B., Jagadish, K., Abhilash, M.R., Namratha, K. and Srikantaswamy, S. (2019) Comparative Study on the Effects of Surface Area, Conduction Band and Valence Band Positions

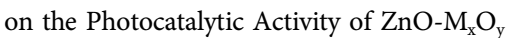
Heterostructures. Journal of Water Resource and Protection, 11, 357-370. https://doi.org/10.4236/jwarp.2019.113021

Received: February 6, 2019

Accepted: March 25, 2019

Published: March 28, 2019

Copyright $\odot 2019$ by author(s) and Scientific Research Publishing Inc. This work is licensed under the Creative Commons Attribution International License (CC BY 4.0).

http://creativecommons.org/licenses/by/4.0/

\begin{abstract}
$\mathrm{ZnO}-\mathrm{M}_{\mathrm{x}} \mathrm{O}_{\mathrm{y}}$ heterostructures $(\mathrm{M}=\mathrm{Co}, \mathrm{Mn}, \mathrm{Ni}$, or $\mathrm{In})$ are fabricated via hydrothermal synthesis method. X-ray diffraction and Fourier-transform infrared spectroscopy analyses endorse the successive formation of the various heterostructures. Field Emission Scanning electron microscope and Brunauer-Emmett-Teller (BET) surface area studies confirm the porous nature of the heterostructures obtained. The band gaps of various heterostructures are calculated that, 3.1, 2.71, 2.64, and $2.19 \mathrm{eV}$ for $\mathrm{ZnO}-\mathrm{NiO}, \mathrm{ZnO}-\mathrm{In}_{2} \mathrm{O}_{3}$, $\mathrm{ZnO}-\mathrm{Co}_{3} \mathrm{O}_{4}$, and $\mathrm{ZnO}-\mathrm{MnO}_{2}$, respectively. The photocatalytic activities of the fabricated heterostructures are investigated through the degradation of phenol under direct sunlight irradiation. The results show that the photocatalytic activity is affected by the conduction band (CB) and valence band (VB) positions rather than surface area of $\mathrm{ZnO}-\mathrm{M}_{\mathrm{x}} \mathrm{O}_{\mathrm{y}}$ heterostructure nanocomposites.
\end{abstract}

\section{Keywords}

Metal Oxide Heterostructures, $\mathrm{ZnO}-\mathrm{M}_{\mathrm{x}} \mathrm{O}_{\mathrm{y}}$ Nanocomposites, Hydrothermal Synthesis, Solar-Driven Photocatalysis, Phenol Degradation

\section{Introduction}

Water pollution has become one of the serious problems that threaten human life. Photocatalytic degradation is a promising green technology to remove organic and inorganic pollutants from the water. A lot of metal oxide semicon- 
ductors have been explored for photocatalytic pollutant degradation [1] [2]. Zinc oxide $(\mathrm{ZnO})$ semiconductor is extensively used as a photocatalyst in the photodegradation of organic and inorganic pollutants [3]. However, there are several drawbacks linked with the higher rates of charge carrier and recombination, and this can only absorb a small percentage of the solar light in the UV region owing to the wide band gap [4]. Hence, it restricts photocatalytic applications under the visible-light illumination [5] and it has posed a challenge to researchers for the effective utilization in the photocatalytic applications. In order to overcome these limitations, researchers did many attempts to tailor the band gap of $\mathrm{ZnO}$ including intrinsic [6] [7] and extrinsic [8] [9] doping and coupling $\mathrm{ZnO}$ with other semiconductor systems. It is well-known that the introductions of extrinsic or intrinsic defects, which cause defect related states in the form of band tail, promote the extension of photonic absorption to the broader visible region or band gap narrowing. Coupling $\mathrm{ZnO}$ with other narrow band gap semiconductors like $\mathrm{CuO}, \mathrm{Fe}_{2} \mathrm{O}_{3}, \mathrm{WO}_{3}, \mathrm{CdS}, \mathrm{ZnS}$, etc. can reduce the band gap and extend the light absorption range of $\mathrm{ZnO}$ to a broader spectrum of the visible light, and promote electron-hole pair separation under sunlight irradiation in order to achieve higher photocatalytic activity [10]. The present authors have worked on coupled $\mathrm{ZnO}$ with $\mathrm{CeO}_{2}$ and $\mathrm{Bi}_{2} \mathrm{O}_{3}$ to construct $\mathrm{Bi}_{2} \mathrm{O}_{3}-\mathrm{CeO}_{2}-\mathrm{ZnO}$ heterostructure [11]. $\mathrm{Bi}_{2} \mathrm{O}_{3}-\mathrm{CeO}_{2}-\mathrm{ZnO}$ exhibited improved photocatalytic activity due to the extended visible-light photoabsorption range benefited from the presence of $\mathrm{Bi}_{2} \mathrm{O}_{3}$ (small band gap of $2.77 \mathrm{eV}$ ) and efficient separation of photo-induced electrons and holes caused by the vector transfer of electrons and holes among $\mathrm{ZnO}, \mathrm{CeO}_{2}$ and $\mathrm{Bi}_{2} \mathrm{O}_{3}$ [11]. On the other hand, usually the photocatalytic activity of a photocatalyst is strongly influenced by its surface area. The higher surface area, the higher number of active photocatalytic sites, the higher adsorption capability for the pollutants on the photocatalyst surface, and the higher photocatalytic activity [12] [13] [14]. Although there are several methods available to process these metal oxides, but hydrothermal technique is becoming very popular in recent years, because of its environmentally benign and facilitates in situ surface modification, which provides fabrication of nanoparticles with desired tailor-made properties [15] [16] [17] [18]. In the present work, an attempt has been made to understand a unique comparative study on the effects of surface area, $\mathrm{CB}$ and $\mathrm{VB}$ positions and band gap of $\mathrm{ZnO}$ based metal oxide $\left(\mathrm{ZnO} / \mathrm{M}_{\mathrm{x}} \mathrm{O}_{\mathrm{y}}\right)$ heterostructures for their photocatalytic activities, whereas $\mathrm{ZnO} / \mathrm{M}_{\mathrm{x}} \mathrm{O}_{\mathrm{y}}$ are $\mathrm{ZnO} / \mathrm{MnO}_{2}, \mathrm{ZnO} / \mathrm{Co}_{3} \mathrm{O}_{4}, \mathrm{ZnO} / \mathrm{NiO}$ and $\mathrm{ZnO} / \mathrm{In}_{2} \mathrm{O}_{3}$. The photocatalytic efficiency of these coupled semiconductor systems have been tested by monitoring phenol degradation under solar irradiation.

\section{Experimental Details}

\subsection{Materials}

The ingredients were procured through different commercial suppliers as follows: $\mathrm{Zn}\left(\mathrm{NO}_{3}\right)_{2} \cdot 6 \mathrm{H}_{2} \mathrm{O}$ (Alfa Aesar, $99 \%$ ), $\mathrm{Ni}\left(\mathrm{NO}_{3}\right)_{2} \cdot 6 \mathrm{H}_{2} \mathrm{O}$ (Sigma Aldrich, $99.99 \%$, $\mathrm{Co}\left(\mathrm{NO}_{3}\right)_{2} \cdot 6 \mathrm{H}_{2} \mathrm{O}$ (Loba Chemie, 99.8\%), $\mathrm{In}\left(\mathrm{NO}_{3}\right) \cdot \mathrm{xH}_{2} \mathrm{O}$ (Sigma-Aldrich, 99.99\%), 
$\mathrm{Mn}\left(\mathrm{NO}_{3}\right) \cdot 4 \mathrm{H}_{2} \mathrm{O}$ (Alfa Aesar, 98\%) and $\mathrm{NaOH}$ (Sigma-Aldrich, 97\%). Ultra-pure water $(18.2 \mathrm{M} \Omega \cdot \mathrm{cm})$ was used in the experiments.

\subsection{Hydrothermal Synthesis of $\mathrm{ZnO} / \mathrm{M}_{\mathrm{x}} \mathrm{O}_{\mathrm{y}}$ Nanocomposite}

The synthesis of $\mathrm{ZnO} / \mathrm{M}_{\mathrm{x}} \mathrm{O}_{\mathrm{y}}$ nanocomposites were carried out by using $15 \mathrm{ml}$ $0.1 \mathrm{M} \mathrm{Zn}\left(\mathrm{NO}_{3}\right)_{2} \cdot 6 \mathrm{H}_{2} \mathrm{O}$ mixed with $15 \mathrm{ml} 0.1 \mathrm{M}$ along with a desired metal nitrate $\left(\mathrm{Ni}\left(\mathrm{NO}_{3}\right)_{2} \cdot 6 \mathrm{H}_{2} \mathrm{O}, \mathrm{Co}\left(\mathrm{NO}_{3}\right)_{2} \cdot 6 \mathrm{H}_{2} \mathrm{O}, \mathrm{Mn}\left(\mathrm{NO}_{3}\right)_{2} \cdot 4 \mathrm{H}_{2} \mathrm{O}\right.$ or $\left.\mathrm{In}\left(\mathrm{NO}_{3}\right) \cdot x \mathrm{H}_{2} \mathrm{O}\right)$. The mixed solution was ultrasonicated thoroughly and mixed for 30 minutes to get the homogenous mixture. Later, about $24 \mathrm{ml}$ of the suspension was transferred into a $30 \mathrm{ml}$ capacity Teflon liner and closed tightly. The percent fill was kept at $80 \%$ in all experiments. The Teflon liner was inserted into SS316 Stainless Steel autoclave and heated up to a particular temperature for a required period of time (Table 1). The autoclave was cooled down to the laboratory temperature after hydrothermal reaction and the resultant material in the Teflon liner was filtered and washed with distilled water and ethanol. Later, the product obtained was dried at around $80^{\circ} \mathrm{C}$ in a hot air oven for 12 hours. Table 1 gives the experimental hydrothermal conditions used in the synthesis of $\mathrm{ZnO}^{-} \mathrm{M}_{\mathrm{x}} \mathrm{O}_{\mathrm{y}}$ heterostructure nanocomposites.

\subsection{Characterization}

The prepared heterostructures were characterized using Rigaku Smart Lab-II X-ray diffractometer (XRD) with CuK $\alpha$ radiation $(\lambda=1.540598 \AA$ ), Carl Zeiss MERLIN Compact field emission scanning electron microscopy (FE-SEM), JASCO 460 plus FTIR spectrometer, a Shimadzu UV-2450 spectrophotometer (UV-Vis DRS), NETZSCH, Germany, Model STA 2500 Regulus, thermo-gravimetric analysis (TGA), and BELSORP MINI 2, BEL, Japan, Brunauer-Emmett-Teller (BET) surface area measurements.

\subsection{Photocatalytic Test}

The photocatalytic properties of as synthesized $\mathrm{ZnO}-\mathrm{M}_{\mathrm{x}} \mathrm{O}_{\mathrm{y}}$ nanocomposites were carried out for the study of phenol degradation. The degradation was performed under solar light irradiation to the phenol sample with the catalyst $\mathrm{ZnO}-\mathrm{M}_{\mathrm{x}} \mathrm{O}_{\mathrm{y}}$ nanocomposites. The phenol samples with different concentrations, like 8, 16, 24 and $32 \mathrm{ppm}$, were prepared and the optimum phenol degradation concentration was investigated for the different catalysts. In typical procedure, the degradation

Table 1. Experimental conditions used in the fabrication of $\mathrm{M}_{\mathrm{x}} \mathrm{O}_{\mathrm{y}}$ nanocomposites.

\begin{tabular}{cccc}
\hline $\mathrm{ZnO} / \mathrm{M}_{\mathrm{x}} \mathrm{O}_{\mathrm{y}}$ composite & Ratio & Temperature $\left({ }^{\circ} \mathrm{C}\right)$ & Hydrothermal reaction time duration $(\mathrm{hr})$ \\
\hline $\mathrm{ZnO} / \mathrm{MnO}_{2}$ & $1: 1$ & 180 & 5 \\
$\mathrm{ZnO} / \mathrm{NiO}$ & $1: 1$ & 160 & 5 \\
$\mathrm{ZnO} / \mathrm{Co}_{3} \mathrm{O}_{4}$ & $1: 1$ & 150 & 6 \\
$\mathrm{ZnO} / \mathrm{In}_{2} \mathrm{O}_{3}$ & $1: 1$ & 180 & 8 \\
\hline
\end{tabular}


was carried out by preparing $100 \mathrm{ml}$ of phenol solution with above mentioned different concentration in a $250 \mathrm{~cm}^{3}$ conical flasks. Later, $0.5 \mathrm{~g}$ of the catalysts such as $\mathrm{ZnO}-\mathrm{M}_{\mathrm{x}} \mathrm{O}_{\mathrm{y}}$ nanocomposites were added to individual flasks and closed tightly with rubber cork. The degradation reaction was carried out for the period of $3 \mathrm{~h}$ (from 11 am to $2 \mathrm{am}$ in a sunny day in April 2018 in Mysuru, India) under solar light irradiation. After the completion of degradation reaction, the samples were filtered and the percentage of phenol degradation was investigated by performing chemical oxygen demand (COD) analysis.

\section{Results and Discussion}

\subsection{The Powder XRD Analysis}

Figure 1 shows the powder $\mathrm{XRD}$ patterns of pure $\mathrm{ZnO}$ and heterogeneous semiconductor $\mathrm{ZnO}-\mathrm{M}_{\mathrm{x}} \mathrm{O}_{\mathrm{y}}$ nanocomposites. It is clear indicates that, all the diffraction peaks of $\mathrm{ZnO}$ can be indexed to the hexagonal wurtzite structure according to JCPDS card N (JCPDS: 36-1451) [19] and peaks corresponds to heterostructured composites consist of different phases. The XRD pattern of heterostructured $\mathrm{ZnO}-\mathrm{Co}_{3} \mathrm{O}_{4}$ composite indicates that it consists of two kinds of phases, hexagonal $\mathrm{ZnO}$ and spinel structured cubic $\mathrm{Co}_{3} \mathrm{O}_{4}$ (JCPDS card \# 43-1003) confirming the coexistence of $\mathrm{Zn}$ and $\mathrm{Co}$ oxide structure together to form a composite however, the peaks of $\mathrm{Co}_{3} \mathrm{O}_{4}$ are weak compared with $\mathrm{ZnO}$ and it is matched with the data reported by Zhang et al. [20]. The XRD pattern of heterostructured $\mathrm{ZnO}-\mathrm{NiO}$ composite indicates that it consists of two phases, hexagonal $\mathrm{ZnO}$ and cubic structured rocksalt type $\mathrm{NiO}$ phase (JCPDS-78-0643) showing the coexistence of $\mathrm{Zn}$ and $\mathrm{Ni}$ oxide structures together to form heterogeneous composite. The XRD pattern of heterostructured $\mathrm{ZnO}-\mathrm{MnO}_{2}$ composite specifies that it consists of two kind of phases, hexagonal $\mathrm{ZnO}$ and birnessite $\delta-\mathrm{MnO}_{2}$ crystal phase (JCPDS 80-1098) [21] which indicates that the coexistence of $\mathrm{Zn}$ and $\mathrm{Mn}$ oxide structures together to form heterogeneous heterostructure

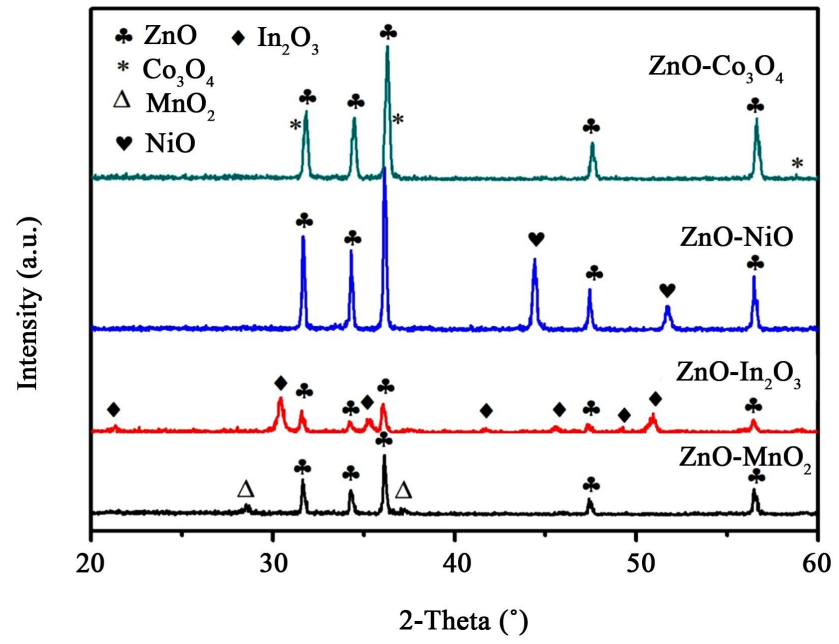

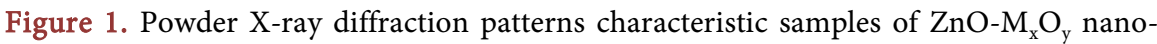
composites. 
composite [22]. The powder XRD pattern of heterostructured $\mathrm{ZnO}-\operatorname{In}_{2} \mathrm{O}_{3}$ composite postulates that it consists of two kind of phases, hexagonal $\mathrm{ZnO}$ and bixbyite type $\mathrm{In}_{2} \mathrm{O}_{3}$ of cubic system crystal phase indicates that the coexistence of $\mathrm{Zn}$ and In oxide structures together to form heterogeneous composite. The XRD pattern of $\mathrm{ZnO}-\mathrm{In}_{2} \mathrm{O}_{3}$ is in agreement with the earlier reported pattern [23]. The intensity of standard $\mathrm{ZnO}$ decreased in all heterogeneous composites, due to the major reflections of other metal oxides which were entrapped in intense $\mathrm{ZnO}$ reflections. This mechanism leads to the growth of heterogeneous composites with different crystal phases. The powder patterns show well crystallized metal oxides with a higher degree of crystallinity forming $\mathrm{M}_{\mathrm{x}} \mathrm{O}_{\mathrm{y}}$ nanocomposites.

\subsection{FTIR Analysis}

The FTIR analysis of heterostructured $\mathrm{ZnO}-\mathrm{M}_{\mathrm{x}} \mathrm{O}_{\mathrm{y}}$ nanocomposites was performed. Figure 2 shows the FTIR spectra and the bands are observed near $3445 \mathrm{~cm}^{-1}$ and $1630 \mathrm{~cm}^{-1}$ correspond to the $\mathrm{O}-\mathrm{H}$ stretching and bending vibration of water molecules adsorbed on the surface of nanocomposites due to the porosity as noticed in the images of electron microscopic study.

The carbonate peaks are prominent in all the composites and it is again attributed to the absorption of $\mathrm{CO}_{2}$ from the atmosphere. The finger print region of metal oxygen bond shows the characteristic absorption bands in the wavenumber region 400 to $600 \mathrm{~cm}^{-1}$ [11]. This finger print range shows the metal oxygen bond presence of different metal oxygen of $\mathrm{ZnO}-\mathrm{M}_{\mathrm{x}} \mathrm{O}_{\mathrm{y}}$ nanocomposites. Usually $\mathrm{ZnO}$ shows flower like, or interlocked rod like structure, and other metal oxides like $\mathrm{CO}_{3} \mathrm{O}_{4}, \mathrm{In}_{2} \mathrm{O}_{3}, \mathrm{NiO}$, and $\mathrm{MnO}_{2}$, show a different morphology (either tabular, or massive rounded to sub-rounded). The bonding of composites have metal and oxygen bond between $\mathrm{Zn}-\mathrm{O}, \mathrm{Ni}-\mathrm{O}, \mathrm{Mn}-\mathrm{O}, \mathrm{In}-\mathrm{O}$ and Co-O along with the absorption peak at wavenumber range $1402-1506 \mathrm{~cm}^{-1}$ indicates the presence of $\mathrm{CO}_{2}$, which was due to the atmospheric $\mathrm{CO}_{2}$ interference during analysis [11] [19]. Apparently, the FTIR results further support the formation

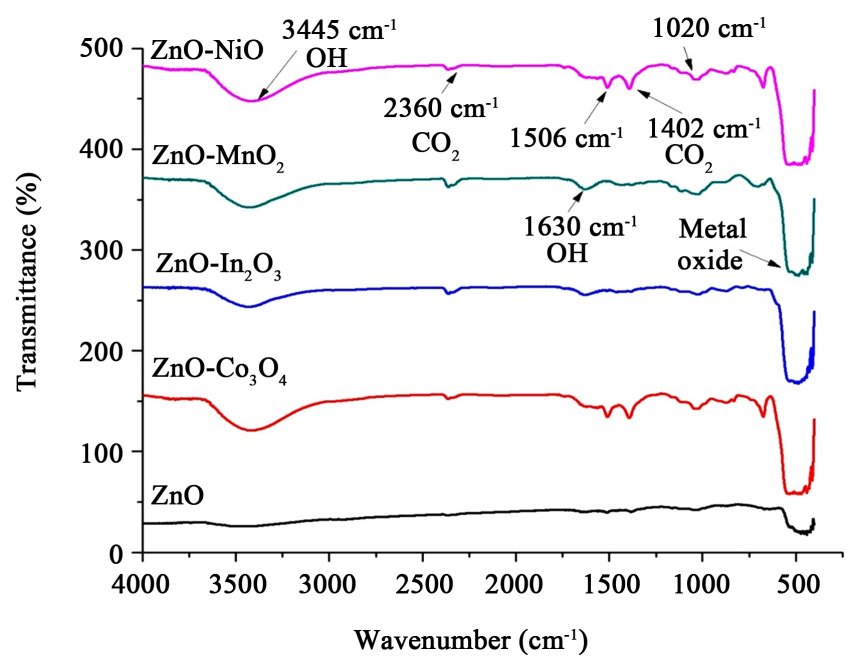

Figure 2. Characteristic FTIR spectra of $\mathrm{ZnO}-\mathrm{M}_{\mathrm{x}} \mathrm{O}_{\mathrm{y}}$ nanocomposites. 
of the heterostructured nanocomposites and agree well with XRD results.

\subsection{FESEM Analysis}

Figure 3 shows FE-SEM images of $\mathrm{ZnO}-\mathrm{M}_{\mathrm{x}} \mathrm{O}_{\mathrm{y}}$ nanocomposites and it is observed that $\mathrm{ZnO}-\mathrm{Co}_{3} \mathrm{O}_{4}$ and $\mathrm{ZnO}-\mathrm{In}_{2} \mathrm{O}_{3}$ show fine interlocked nanorods showing porous structure, whereas $\mathrm{ZnO}-\mathrm{NiO}$ and $\mathrm{ZnO}-\mathrm{MnO}_{2}$ show still finer structures with smaller rods and also showing the interlocked porous structure. This is a very typical characteristic of $\mathrm{ZnO}-\mathrm{M}_{\mathrm{x}} \mathrm{O}_{\mathrm{y}}$ nanocomposites. It is further observed that the particles have narrow-size distribution. The average particle size distribution of $\mathrm{ZnO}-\mathrm{M}_{\mathrm{x}} \mathrm{O}_{\mathrm{y}}$ nanocomposites is shown in Figure 4. Among the nanocomposites synthesized, $\mathrm{ZnO}-\operatorname{In}_{2} \mathrm{O}_{3}$ have highest particle size $(140 \mathrm{~nm})$ and $\mathrm{ZnO}-\mathrm{NiO}$ have the least particle size $(40 \mathrm{~nm})$. This kind of interlocked structure shows higher porosity and in turn higher BET surface area. It is also evident from FTIR spectra that, $\mathrm{ZnO}-\mathrm{M}_{\mathrm{x}} \mathrm{O}_{\mathrm{y}}$ nanocomposites have the surface adsorption of $\mathrm{CO}_{2}$ and $\mathrm{O}-\mathrm{H}$.

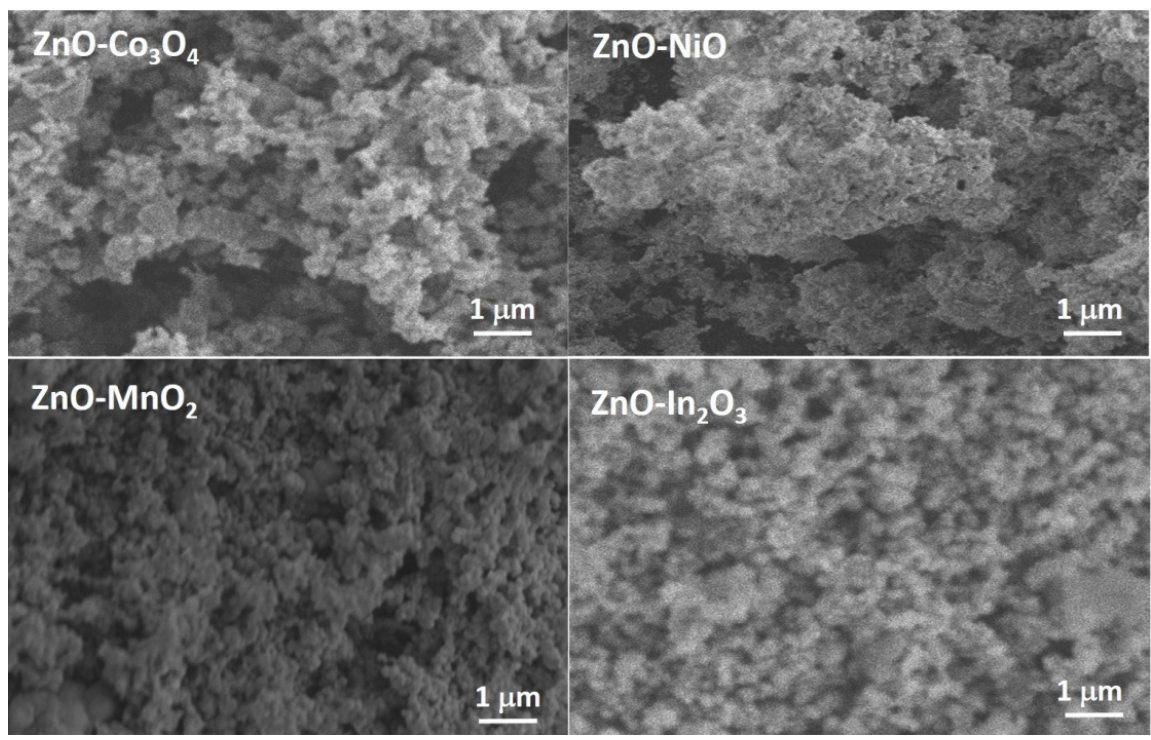

Figure 3. FESEM images of characteristic $\mathrm{ZnO} / \mathrm{M}_{\mathrm{x}} \mathrm{O}_{\mathrm{y}}$ nanocomposites.

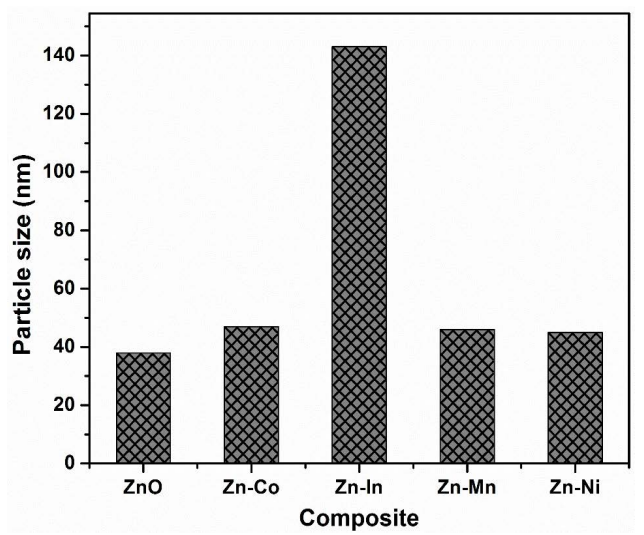

Figure 4. Particle size distribution of $\mathrm{ZnO}-\mathrm{M}_{\mathrm{x}} \mathrm{O}_{\mathrm{y}}$ nanocomposites. 


\subsection{DLS Analysis}

Particle size distributions of as prepared nanocomposites are shown in Figure 4. The analysis was carried out by DLS instrument, in which the size measurement was based on the Brownian motion of particle in the solvent media. The results as evident from Figure 4, indicate that the average particle size $(\mathrm{nm})$ of the nanocomposites prepared by hydrothermal reaction conditions. The average particle size of pure $\mathrm{ZnO}$, composites $\mathrm{ZnO}-\mathrm{Co}_{3} \mathrm{O}_{4}, \mathrm{ZnO}-\mathrm{In}_{2} \mathrm{O}_{3}, \mathrm{ZnO}-\mathrm{MnO}_{2}$ and $\mathrm{ZnO}-\mathrm{NiO}$ was $38,47,143,46$ and 44 respectively. The pure $\mathrm{ZnO}$ shows the lowest and composite $\mathrm{ZnO}-\mathrm{In}_{2} \mathrm{O}_{3}$ shows highest average particle size. The results obtained from DLS corresponding with the results of FESEM images. It was described that the highest particle size from the composite $\mathrm{ZnO}-\mathrm{In}_{2} \mathrm{O}_{3}$ due to the high atomic/ionic radius ( $167 \mathrm{pm}$ ) of Indium atom, when compared to the other metals from the composite. Further the composites, prepared from the hydrothermal reaction show the size within $100 \mathrm{~nm}$ range except $\mathrm{ZnO}-\mathrm{In}_{2} \mathrm{O}_{3}$ and indicates that the confirmation of nanocomposite formation.

\subsection{UV-Vis Spectroscopic Analysis}

The DRS UV-Vis spectra of as-synthesized $\mathrm{ZnO}-\mathrm{M}_{\mathrm{x}} \mathrm{O}_{\mathrm{y}}$ nanocomposites were recorded to determine their light absorption characteristics and Figure 5 shows the DRS UV-Vis spectra of heterostructured nanocomposites. $\mathrm{ZnO}-\mathrm{MnO}_{2}$ shows the highest visible light absorption while $\mathrm{ZnO}-\mathrm{NiO}$ shows the lowest visible light absorption. The band gaps of the various heterostructures were obtained from Tauc plot displayed in Figure 5(b) [24] [25]. Obviously, the band gap of the four heterostructures followed the trend of $\mathrm{ZnO}-\mathrm{NiO}(3.1 \mathrm{eV})>\mathrm{ZnO}-\mathrm{In}_{2} \mathrm{O}_{3}(2.71$ $\mathrm{eV})>\mathrm{ZnO}-\mathrm{Co}_{3} \mathrm{O}_{4}(2.64 \mathrm{eV})>\mathrm{ZnO}-\mathrm{MnO}_{2}(2.19 \mathrm{eV})$.

\subsection{TGA Analysis}

The thermal analysis of as synthesized $\mathrm{ZnO}-\mathrm{M}_{\mathrm{x}} \mathrm{O}_{\mathrm{y}}$ nanocomposites was carried out to get information about change in composites properties as function of temperature. Figure 6 shows the TGA curves obtained under inert nitrogen environment for the nanocomposites. TGA curve indicate that the change in weight loss (\%). The TGA curve of $\mathrm{ZnO}-\mathrm{Co}_{3} \mathrm{O}_{4}$ shown that, the gradual decrease

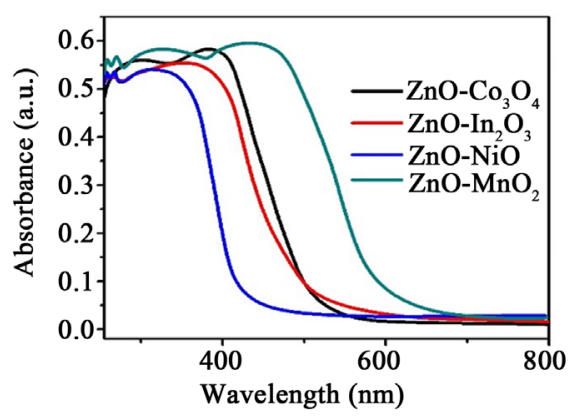

(a)

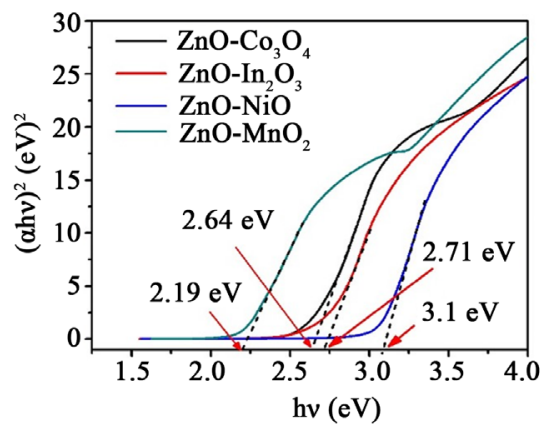

(b)

Figure 5. UV-Vis absorbance spectrum and Tauc plot of $\mathrm{ZnO}-\mathrm{M}_{\mathrm{x}} \mathrm{O}_{\mathrm{y}}$ nanocomposites. 


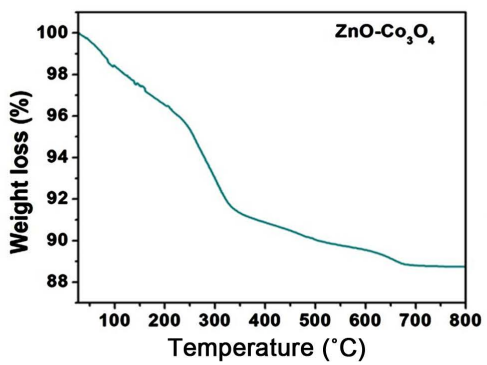

(a)

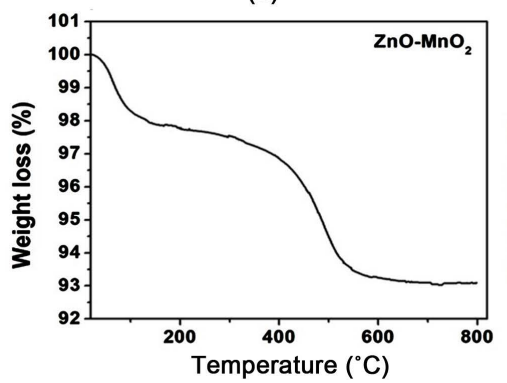

(c)

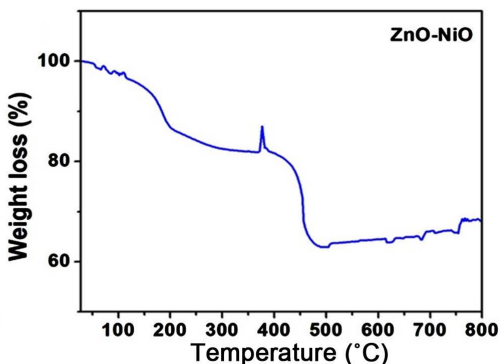

(b)

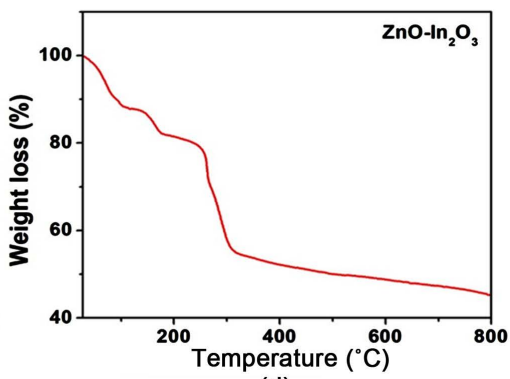

(d)

Figure 6. TGA curves of $\mathrm{ZnO}-\mathrm{M}_{\mathrm{x}} \mathrm{O}_{\mathrm{y}}$ nanocomposites.

in the weight at $105^{\circ} \mathrm{C}$, attributed to the evaporation of any residual water. Further decrease in the weight loss up to $290^{\circ} \mathrm{C}$ was due to the evaporation of $\mathrm{CO}_{2}$. The presence of $\mathrm{CO}_{2}$ was evident from the FTIR analysis as well as the sudden loss in the weight $\%$ at temperature $290^{\circ} \mathrm{C}$ to $350^{\circ} \mathrm{C}$ was due to the decomposition of $\mathrm{Co}_{3} \mathrm{O}_{4}$ which in turn form $\mathrm{Co}_{3} \mathrm{O}_{4}$ and $\mathrm{O}_{2}$. The total weight loss of $\mathrm{ZnO}-\mathrm{Co}_{3} \mathrm{O}_{4}$ was $\sim 15 \%$ and it shows high thermal stability. TGA curve at the temperature range between $40^{\circ} \mathrm{C}-180^{\circ} \mathrm{C}$ and $190^{\circ} \mathrm{C}-375^{\circ} \mathrm{C}$ of $\mathrm{ZnO}-\mathrm{NiO}$ composite shows the weight loss occurred due to evaporation of water and $\mathrm{CO}_{2}$ respectively. Again the sudden increase in the weight at temperature range between $380^{\circ} \mathrm{C}-390^{\circ} \mathrm{C}$ occurred due to the re-adsorption of $\mathrm{CO}_{2}$ with the influence of fluid $\mathrm{N}_{2}$. Further the sudden decrease in the weight loss at temperature between $440^{\circ} \mathrm{C}-520^{\circ} \mathrm{C}$ was due to the decomposition of composites. The TGA curve of $\mathrm{ZnO}-\mathrm{MnO}_{2}$ composite shows the curve with gradual decrease in the weight loss at temperature $40^{\circ} \mathrm{C}-150^{\circ} \mathrm{C}$ due to evaporation of water molecules. Further the weight loss at temperature $420^{\circ} \mathrm{C}-550^{\circ} \mathrm{C}$ was due to the thermal decomposition of $\mathrm{ZnO}-\mathrm{MnO}_{2}$ to $\mathrm{MnO}_{2}$, and also the total weight loss observed was only $\sim 8 \%$, which depicts the higher thermal stability. The TGA of $\mathrm{ZnO}-\mathrm{In}_{2} \mathrm{O}_{3}$ composite shows that the gradual decrease of weight loss at $40^{\circ} \mathrm{C}$ $120^{\circ} \mathrm{C}$ and $150^{\circ} \mathrm{C}-240^{\circ} \mathrm{C}$ indicate the evaporation of water and $\mathrm{CO}_{2}$ respectively. Further the sudden decrease in the weight loss at $280^{\circ} \mathrm{C}-330^{\circ} \mathrm{C}$ was due to the decomposition of composite, with a larger weight loss (35\%).

\subsection{BET Surface Area}

The $\mathrm{N}_{2}$ sorption isotherms of all samples can be classified as type IV with $\mathrm{H}_{3}$ hysteresis loops (Figure 7), which means the existence of slit-like mesopores (2 $50 \mathrm{~nm}$ ) formed between aggregated nanoparticles [26]. The hysteresis loops of 
all samples spanned a large $\mathrm{P} / \mathrm{P} 0$ range $(0.3-1.0)$, corresponding to the presence of mesopores. The surface area of the various samples follows the order: $\mathrm{ZnO}-\mathrm{MnO}_{2}\left(58.4 \mathrm{~m}^{2} / \mathrm{g}\right)>\mathrm{ZnO}-\mathrm{NiO}\left(41.6 \mathrm{~m}^{2} / \mathrm{g}\right)>\mathrm{ZnO}-\mathrm{Co}_{3} \mathrm{O}_{4}\left(39.6 \mathrm{~m}^{2} / \mathrm{g}\right)>$ $\mathrm{ZnO}-\mathrm{In}_{2} \mathrm{O}_{3}\left(22.7 \mathrm{~m}^{2} / \mathrm{g}\right)$. In comparison with DLS results, the lowest surface area is shown by $\mathrm{ZnO}-\mathrm{In}_{2} \mathrm{O}_{3}$ with the larger particle size. The pore size distribution of the samples (Figure 7) further confirms the formation of mesopores. As can be seen, the pore size distribution curve is quite broad (from 2 to $100 \mathrm{~nm}$ ) with small and large mesopores (in the range of $2-50 \mathrm{~nm}$ ). The small mesopores may reflect porosity within the nanoparticles and the large mesopores are associated to the pores formed between the nanoparticles [27].

\subsection{Photocatalytic Properties of $\mathrm{ZnO}-\mathrm{M}_{\mathrm{x}} \mathrm{O}_{\mathrm{y}}$ Nanocomposites}

The photocatalytic activities of the as prepared nanocomposites were performed by using phenol as a model organic pollutant in an aqueous solution for the degradation process. Figure 8 shows Chemical Oxygen Demand level of phenol

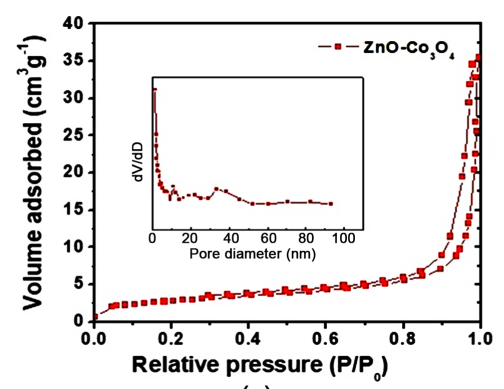

(a)

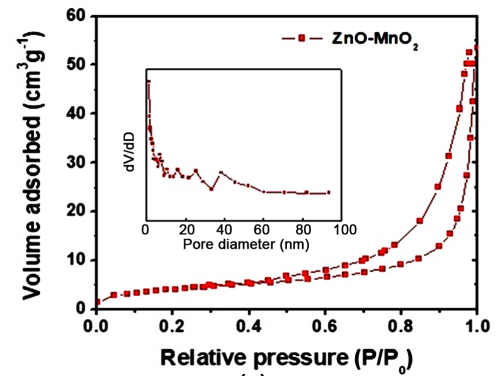

(c)

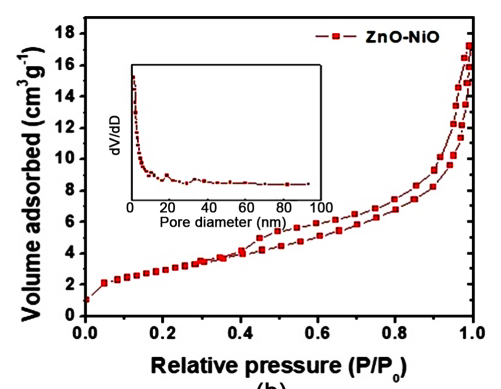

(b)

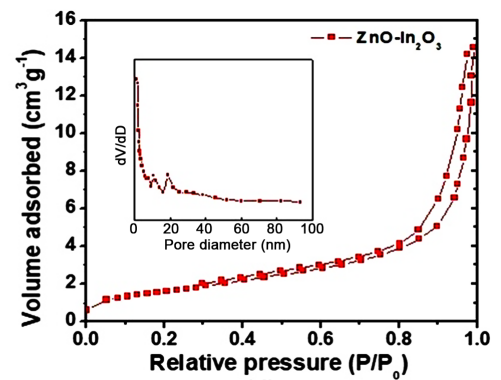

(d)

Figure 7. BET $\mathrm{N}_{2}$ adsorption isotherm of $\mathrm{ZnO}-\mathrm{M}_{\mathrm{x}} \mathrm{O}_{\mathrm{y}}$ nanocomposites.

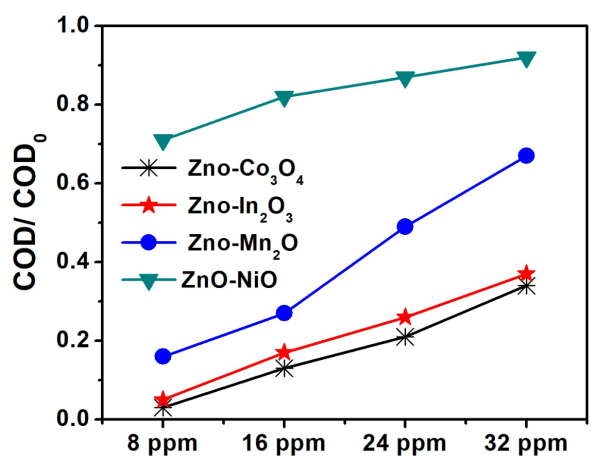

Figure 8. COD of $\mathrm{ZnO}-\mathrm{M}_{\mathrm{x}} \mathrm{O}_{\mathrm{y}}$ nanocomposites. 
degradation in different concentrations of various composites under sunlight irradiation for the period of 3 hours. The order of phenol degradation follows the trends: $\mathrm{ZnO}-\mathrm{Co}_{3} \mathrm{O}_{4}>\mathrm{ZnO}-\mathrm{In}_{2} \mathrm{O}_{3}>\mathrm{ZnO}-\mathrm{MnO}_{2}>\mathrm{ZnO}-\mathrm{NiO}$. Apparently, the order of phenol degradation does not follow the order of surface area, but it may occur because of the chemical composition of composites. The photocatalytic degradation was maximum by using $\mathrm{ZnO}-\mathrm{Co}_{3} \mathrm{O}_{4}$, where $97 \%$ of $8 \mathrm{ppm}$ of phenol have been degraded followed with $95 \%$ degradation by $\mathrm{ZnO}-\mathrm{In}_{2} \mathrm{O}_{3}, 84 \%$ degradation by $\mathrm{ZnO}-\mathrm{MnO}_{2}$ and $29 \%$ degradation by $\mathrm{ZnO}-\mathrm{NiO}$ respectively. The degradation efficiency decreased when the concentration of phenol increased from 8 ppm to $32 \mathrm{ppm}$, which may be due to phenol molecules around the photocatalytic active sites resulted in inhibiting the penetration of light to the surface of the catalyst. Hence, the generation of relative amount of ${ }^{\circ} \mathrm{OH}$ and ${ }^{\prime} \mathrm{O}_{2}^{-}$on the surface of the catalyst decreased [28]. The heterostructure catalysts were further tested for repetitive processes of photocatalytic degradation. It was found that the photocatalytic degradation efficiency did not decrease even after 3 cycles of photodegradation.

\subsection{Plausible Mechanism of Phenol Degradation}

The band gaps and band positions were calculated and the band structure diagrams of the different nanocomposites were presented in Figure 9, which is

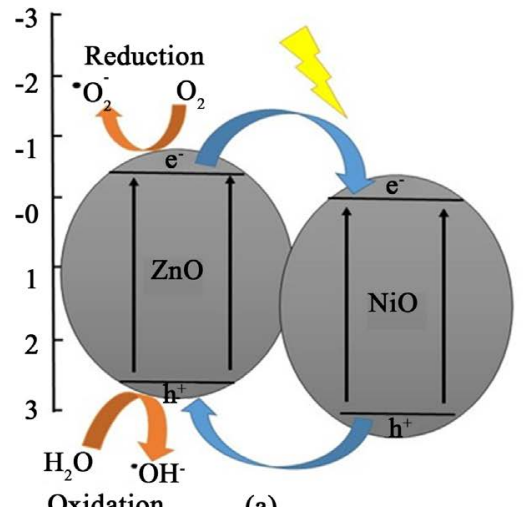

(a)

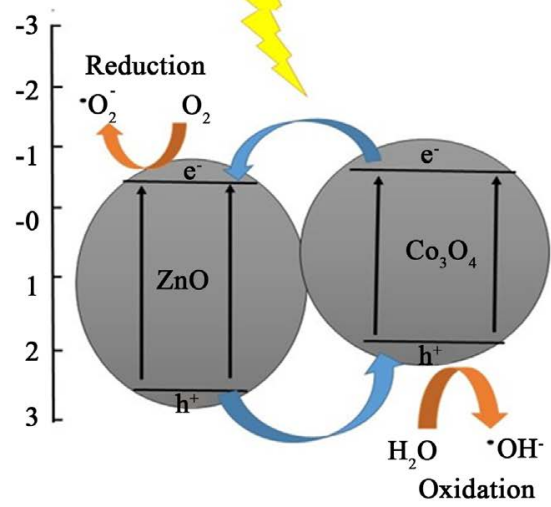

(c)

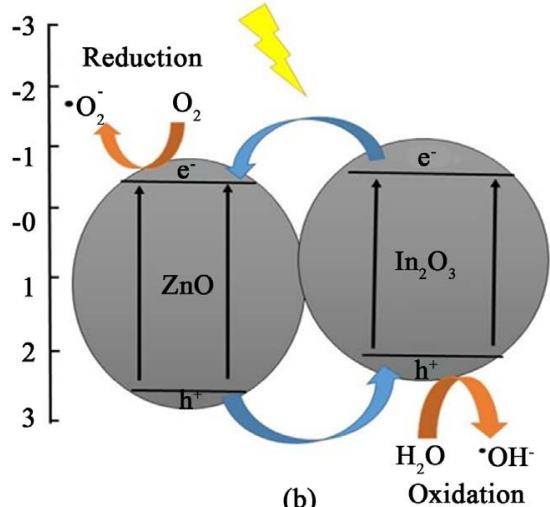

(b)

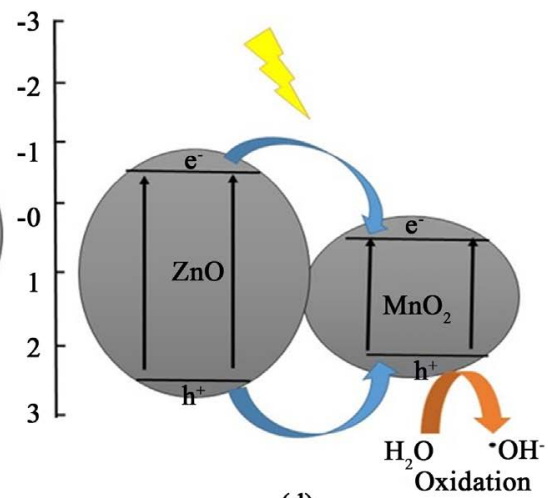

(d)

Figure 9. Photocatalysis mechanism of $\mathrm{ZnO}-\mathrm{M}_{\mathrm{x}} \mathrm{O}_{\mathrm{y}}$ nanocomposites. 
helpful in understanding the mechanism of phenol degradation. The enhancement in the photocatalytic activity of $\mathrm{ZnO}-\mathrm{Co}_{3} \mathrm{O}_{4}$ and $\mathrm{ZnO}-\mathrm{In}_{2} \mathrm{O}_{3}$ can be attributed to the small band gap of $\mathrm{ZnO}-\mathrm{In}_{2} \mathrm{O}_{3}(2.71 \mathrm{eV})$ and $\mathrm{ZnO}-\mathrm{Co}_{3} \mathrm{O}_{4}(\sim 2.64 \mathrm{eV})$ which results in improving the visible light absorption, and the enhancement in the charge separation occurs because of coupling $\mathrm{ZnO}$ with $\mathrm{Co}_{3} \mathrm{O}_{4}$ and $\operatorname{In}_{2} \mathrm{O}_{3}$ separately [29] [30] [31]. In case of $\mathrm{Co}_{3} \mathrm{O}_{4}-\mathrm{ZnO}$ nanocomposite, the electrons are accumulated in the conduction band (CB) of $\mathrm{ZnO}$ and the holes in the valance band (VB) of $\mathrm{Co}_{3} \mathrm{O}_{4}$ because the difference in the band edges positions. Similarly, in $\mathrm{In}_{2} \mathrm{O}_{3}-\mathrm{ZnO}$ nanocomposite, the electrons migrate to the $\mathrm{CB}$ of $\mathrm{ZnO}$ and the holes to the $\mathrm{VB}$ of $\operatorname{In}_{2} \mathrm{O}_{3}$ leading to inhibiting the electron hole recombination and enhancing the charge carrier separation efficiency and thus enhanced the photocatalytic activity. The electronic structure and band gap movement and also defect states have been studied in detail using XPS and photoluminescence spectroscopy. These results will be published elsewhere as a part of a detailed mechanism for heterostructure metal oxides nanocomposites.

Although the band gap of $\mathrm{ZnO}-\mathrm{MnO}_{2}(2.19 \mathrm{eV})$ is smaller than $\mathrm{ZnO}-\mathrm{In}_{2} \mathrm{O}_{3}$, $\mathrm{ZnO}-\mathrm{Co}_{3} \mathrm{O}_{4}$ and $\mathrm{ZnO}-\mathrm{NiO}$ shows lower photocatalytic activity and the reason is charge separation efficiency of $\mathrm{ZnO}-\mathrm{MnO}_{2}$ is very low when compared with $\mathrm{ZnO}-\mathrm{Co}_{3} \mathrm{O}_{4}$ and $\mathrm{ZnO}-\mathrm{In}_{2} \mathrm{O}_{3}$. This process is indicated clearly in Figure 9, where the electrons and holes are accumulated in the $\mathrm{CB}$ and $\mathrm{VB}$ of $\mathrm{MnO}_{2}$ which leads to high electron-hole recombination rate and thereby low photocatalytic activity. Moreover, the $\mathrm{CB}$ edge of $\mathrm{MnO}_{2}$ is lower than the potential required to produce superoxide radicals $\left({ }^{\circ} \mathrm{O}_{2}^{-}\right)$, hence only hydroxyl radicals $\left({ }^{\circ} \mathrm{OH}\right)$ take part in the phenol degradation over $\mathrm{ZnO}-\mathrm{MnO}_{2}$ leading to further decrease in the photocatalytic activity [32]. The low photocatalytic activity of $\mathrm{ZnO}-\mathrm{NiO}$ under sunlight irradiation due to the large band gap of $\mathrm{ZnO}-\mathrm{NiO}(3.1 \mathrm{eV})$ leads to low light absorption and hence low photocatalytic activity occurred.

\section{Conclusion}

$\mathrm{ZnO}-\mathrm{Co}_{3} \mathrm{O}_{4}, \mathrm{ZnO}-\mathrm{In}_{2} \mathrm{O}_{3}, \mathrm{ZnO}-\mathrm{MnO}_{2}$, and $\mathrm{ZnO}-\mathrm{NiO}$ heterostructures were fabricated via facile hydrothermal route. The successive formation of heterostructures and their purity were confirmed by XRD analysis. FT-IR analysis further verified that fabricated heterostructures are metal oxides and no other impurities. SEM and BET studies revealed that the heterostructures obtained exhibit porous nature. TGA analysis shows that the highest and lowest thermal stability were exhibited by $\mathrm{ZnO}-\mathrm{MnO}_{2}$ and $\mathrm{ZnO}-\mathrm{In}_{2} \mathrm{O}_{3}$ respectively. The band gap of the prepared heterostructures follows the trend: $\mathrm{ZnO}-\mathrm{NiO}(3.1 \mathrm{eV})>\mathrm{ZnO}-\mathrm{In}_{2} \mathrm{O}_{3}$ $(2.71 \mathrm{eV})>\mathrm{ZnO}-\mathrm{Co}_{3} \mathrm{O}_{4}(2.64 \mathrm{eV})>\mathrm{ZnO}-\mathrm{MnO}_{2}(2.19 \mathrm{eV})$. The photocatalytic activity was influenced by the electronic structure and the band gap of heterostructure rather than its surface area. The photocatalytic activity follows the order: $\mathrm{Co}_{3} \mathrm{O}_{4}-\mathrm{ZnO}>\mathrm{In}_{2} \mathrm{O}_{3}-\mathrm{ZnO}>\mathrm{ZnO}-\mathrm{MnO}_{2}>\mathrm{ZnO}-\mathrm{NiO}$. The low charge separation efficiency of $\mathrm{ZnO}-\mathrm{MnO}_{2}$ and its inappropriate $\mathrm{CB}$ edge position are the reasons for lower photocatalytic activity than $\mathrm{Co}_{3} \mathrm{O}_{4}-\mathrm{ZnO}$ and $\mathrm{ZnO}-\mathrm{In}_{2} \mathrm{O}_{3}$ with higher band gaps. 


\section{Acknowledgements}

Authors wish to acknowledge the financial support and the laboratory facilities to carry out this work under UGC-UPE project, Govt. of India. FE-SEM work was carried out at Mangalore University, India.

\section{Conflicts of Interest}

The authors declare no conflicts of interest regarding the publication of this paper.

\section{References}

[1] Wang, H.L., Zhang, L.S., Chen, Z.G., Hu, J.Q., Li, S.J., Wang, Z.H., et al. (2014) Semiconductor Heterojunction Photocatalysts: Design, Construction, and Photocatalytic Performances. Chemical Society Reviews, 43, 5234-5244.

[2] Pirhashemi, M., AHabibi-Yangjeh, A. and Rahim Pouran, S. (2018) Review on the Criteria Anticipated for the Fabrication of Highly Efficient ZnO-Based Visible-Light-Driven Photocatalysts. Journal of Industrial and Engineering Chemistry, $62,1-25$.

[3] Gnanaprakasam, A., Sivakumar, V.M., Sivayogavalli, P.L. and Thirumarimurugan, M. (2015) Characterization of $\mathrm{TiO}_{2}$ and $\mathrm{ZnO}$ Nanoparticles and Their Applications in Photocatalytic Degradation of Azodyes. Ecotoxicology and Environmental Safety, 121, 121-125. https://doi.org/10.1016/j.ecoenv.2015.04.043

[4] Wang, C, Xu, B.Q., Wang, X.M. and Zhao, J.C. (2005) Preparation and Photocatalytic Activity of $\mathrm{ZnO} / \mathrm{TiO}_{2} / \mathrm{SnO}_{2}$ Mixture. Journal of Solid State Chemistry, 178, 3500-3506. https://doi.org/10.1016/j.jssc.2005.09.005

[5] Ye, Z., Li, J., Zhou, M., Wang, H., Ma, Y. and Huo, P. (2016) The Histone H3.3K36M Mutation Reprograms the Epigenome of Chondroblastomas. Chemical Engineering Journal, 352, 1344-1348.

[6] Wang, J., Wang, Z., Huang, B., Ma, Y., Liu, Y., Qin, X., Zhang, X. and Dai, Y. (2012) Facile Incorporation of Aggregation-Induced Emission Materials into Mesoporous Silica Nanoparticles for Intracellular Imaging and Cancer Therapy. ACS Applied Materials \&Interfaces, 5, 1943-1947.

[7] Ullatil, S.G., Periyat, P., Naufal, B. and Lazar, M.A. (2016) Self-Doped ZnOMicrorods-High Temperature Stable Oxygen Deficient Platforms for Solar Photocatalysis. Industrial \& Engineering Chemistry Research, 55, 6413-6421. https://doi.org/10.1021/acs.iecr.6b01030

[8] Pasang, T., Namratha, K., Parvin, T., Ranganathaiah, C. and Byrappa, K. (2015) Tuning of Band Gap in $\mathrm{TiO}_{2}$ and $\mathrm{ZnO}$ Nanoparticles by Selective Doping for Photocatalytic Applications. Materials Research Innovations, 19, 73-80. https://doi.org/10.1179/1433075X14Y.0000000217

[9] Namratha, K., Byrappa, S. and Byrappa, K. (2013) Hydrothermal Synthesis, in Situ Surface Modification and Antioxidant Activity of Couple Doped Advanced $\mathrm{ZnO}$ Nanoparticles. Journal of Nanopharmaceutics and Drug Delivery, 1, 258-265. https://doi.org/10.1166/jnd.2013.1026

[10] Chao, X., Cao, L.X., Su, G., Liu, W., Liu, H., Yu, Y.Q. and Qu, X.F. (2010) Preparationof $\mathrm{ZnO} / \mathrm{Cu}_{2} \mathrm{O}$, Compound Photocatalyst and Application in Treating Organic Dyes. Journal of Hazardous Materials, 76, 807-813.

[11] Hezam, A., Namratha, K., Drmosh, Q.A., Yamani, Z.H. and Byrappa, K. (2017) 
Synthesis of Heterostructured $\mathrm{Bi}_{2} \mathrm{O}_{3}-\mathrm{CeO}_{2}-\mathrm{ZnO}$ Photocatalyst with Enhanced Sunlight Photocatalytic Activity. Ceramics International, 43, 5292-5230. https://doi.org/10.1016/j.ceramint.2017.01.059

[12] Haleem, Y.A., He, Q., Liu, D., Wang, C., Xu, W., Gan, W., et al. (2017) Facile Synthesis of Mesoporous Detonation Nanodiamond-Modified Layers of Graphitic Carbon Nitride as Photocatalysts for the Hydrogen Evolution Reaction. RSC Advances, 7, 15390-15396.

[13] Mondal, K. and Sharma, A. (2016) Recent Advances in Synthesis and Application of Photocatalytic Metal-Metal Oxide Core-Shell Nanoparticles for Environmental Remediation and Their Recycling Process. RSC Advances, 6, 83589-83612. https://doi.org/10.1039/C6RA18102C

[14] Li, J.Z., Zhong, J.B., He, X.Y., Huang, S.T., Zeng, J., He, J.J., et al. (2013) Enhanced Photocatalytic Activity of $\mathrm{Fe}_{2} \mathrm{O}_{3}$ Decorated $\mathrm{Bi}_{2} \mathrm{O}_{3}$. Applied Surface Science, 284, 527-532. https://doi.org/10.1016/j.apsusc.2013.07.128

[15] Namratha, K. and Byrappa, K. (2013) Hydrothermal Processing and in Situ Surface Modification of Metal Oxide Nanomaterials. The Journal of Supercritical Fluids, 79, 251-260. https://doi.org/10.1016/j.supflu.2013.01.007

[16] Namratha, K and Byrappa, K. (2012) Novel Solution Routes of Synthesis of Metal Oxide and Hybrid Metal Oxide Nanocrystals. Progress in Crystal Growth and Characterization of Materials, 58, 14-42. https://doi.org/10.1016/j.pcrysgrow.2011.10.005

[17] Keerthana, D.S., Namratha, K., Byrappa, K. and Yathirajan, H.S. (2015) Facile One-Step Fabrication of Magnetite Particles under Mild Hydrothermal Conditions. Journal of Magnetism and Magnetic Materials, 378, 551-557. https://doi.org/10.1016/j.jmmm.2014.10.176

[18] Shubha, P., Namratha, K., Jit Chatterjee, M.S., Mustak, B. and Byrappa, K. (2017) Use of Honey in Stabilization of ZnO Nanoparticles Synthesized via Hydrothermal Route and Assessment of Their Antibacterial Activity and Cytotoxicity. Global Journal of Nanomedicine, 2, Article ID: 555585.

[19] Hezam, A., Namratha, K., Drmosh, Q., Chandrashekar, B.N., Sadasivuni, K.K., Yamaniet, Z.H., et al. (2017) Heterogeneous Growth Mechanism of ZnO Nanostructures and the Effects of Their Morphology on Optical and Photocatalytic Properties. CrystEngComm, 19, 3299-3312. https://doi.org/10.1039/C7CE00609H

[20] Liang, Z., Jing, X., Liu, J., Wang, J. and Sun, Y. (2015) Facile Synthesis of Mesoporous $\mathrm{ZnO} / \mathrm{Co}_{3} \mathrm{O}_{4}$ Microspheres with Enhanced Gas-Sensing for Ethanol. Sensors and Actuators B: Chemical, 221, 1492-1498. https://doi.org/10.1016/j.snb.2015.07.113

[21] Huang, M., Li, F., Li, X., Luo, D., Qiu, X., Zhang, Y. and Li, G. (2015) $\mathrm{MnO}_{2}$-Based Nanostructures for High-Performance Supercapacitors. Electrochimica Acta, 152, 172-177. https://doi.org/10.1016/j.electacta.2014.11.127

[22] Radhamani, A.V., Shareef, K.M. and Ramachandra, M.S. (2016) ZnO@ $\mathrm{MnO}_{2}$ Core-Shell Nanofiber Cathodes for High Performance Asymmetric Supercapacitors. ACS Applied Materials \& Interfaces, 8, 30531-30542. https://doi.org/10.1021/acsami.6b08082

[23] Wang, Z., Huang, B., Dai, Y., Qin, X., Zhang, X., Wang, P., Liu, H. and Yu, J. (2009) HOx Radical Regeneration in the Oxidation of Isoprene. Physical Chemistry Chemical Physics, 11, 5935-5939. https://doi.org/10.1039/b908511d

[24] Tauc, J., Grigorovici, R. and Vancu, A. (1966) Optical Properties and Electronic Structure of Amorphous Germanium. Physica Status Solidi, 15, 627-637.

https://doi.org/10.1002/pssb.19660150224 
[25] Srivastava, M., Das, A.K., Khanra, P., Uddin, M.E., Kim, N.H. and Lee, J.H. (2013) Characterizations of in Situ Grown ceria Nanoparticles on Reduced Graphene Oxide as a Catalyst for the Electrooxidation of Hydrazine. Journal of Materials Chemistry $A, 7,5069-5089$. https://doi.org/10.1039/c3ta11311f

[26] Sing, K.S.W., Everett, D.H., Haul, R., Moscou, L., Pierotti, R.S., Rouquerol, J., et al. (1985) Reporting Physisorption Data for Gas/Solid Systems with Special Reference to the Determination of Surface Area and Porosity. Pure and Applied Chemistry, 57, 603-619. https://doi.org/10.1351/pac198557040603

[27] Dong, F., Zhao, Z., Xiong, T., Ni, Z., Zhang, W., Sun, Y., et al. (2013) Metal-Free Graphitic Carbon Nitride Photocatalyst Goes into Two-Dimensional Time. ACS Applied Materials \& Interfaces, 5, 11392-11401. https://doi.org/10.1021/am403653a

[28] Kumar, K., Amanchi, S.R., Sreedhar, B., Ghosal, P. and Subrahmanyam, C. (2017) Phenol and $\mathrm{Cr}(\mathrm{VI})$ Degradation with $\mathrm{Mn}$ Ion Doped $\mathrm{ZnO}$ under Visible Light Photocatalysis. RSC Advances, 7, 43030-43039.

https://doi.org/10.1039/C7RA08172C

[29] Muñoz-Batista, M.J., Gómez-Cerezo, M.N., Kubacka, A., Tudela, D. and Fernández-García, M. (2014) Role of Interface Contact in $\mathrm{CeO}_{2}-\mathrm{TiO}_{2}$ Photocatalytic Composite Materials. ACS Catalysis, 4, 63-72. https://doi.org/10.1021/cs400878b

[30] Ke, J., Liu, J., Sun, H., Zhang, H., Duan, X., Liang, P., et al. (2017) Facile Assembly of $\mathrm{Bi}_{2} \mathrm{O}_{3} / \mathrm{Bi}_{2} \mathrm{~S}_{3} / \mathrm{MoS}_{2} N$-Pheterojunction with Layered $N-\mathrm{Bi}_{2} \mathrm{O}_{3}$ and $P-\mathrm{MoS}_{2}$ for Enhanced Photocatalytic Water Oxidation and Pollutant Degradation. Applied Catalysis B: Environmental, 200, 47-55. https://doi.org/10.1016/j.apcatb.2016.06.071

[31] Hezam, A., Namratha, K., Lakshmeesha, T.R. and Byrappa, K. (2018) Direct Z-Scheme $\mathrm{Cs}_{2} \mathrm{O}-\mathrm{Bi}_{2} \mathrm{O}_{3}$ - $\mathrm{ZnO}$ Heterostructures as Efficient Sunlight-Driven Photocatalysts. ACS Omega, 3, 12260-12269. https://doi.org/10.1021/acsomega.8b01449

[32] Marschall, R. (2014) Semiconductor Composites: Strategies for Enhancing Charge Carrier Separation to Improve Photocatalytic Activity. Advanced Functional Materials, 24, 2421-2440. https://doi.org/10.1002/adfm.201303214 